\title{
Prolonged Remission of Major Depressive Disorder After Single Nitrous Oxide Inhalation Treatment
}

\author{
Peter Nagele ${ }^{1 *}$, Frank Brown ${ }^{1}$, Victoria Bass ${ }^{1}$ and Daniel Yohanna ${ }^{2}$ \\ 1 Department of Anesthesia and Critical Care, University of Chicago, Chicago, IL, United States, ${ }^{2}$ Department of Psychiatry \\ and Behavioral Neuroscience, University of Chicago, Chicago, IL, United States
}

Keywords: depression, nitrous oxide, remission, psychopharmacology, NMDA receptor

OPEN ACCESS

Edited by:

Colin T. Dourish,

P1 vital Limited, United Kingdom

Reviewed by:

Elena Martín-García,

Pompeu Fabra University, Spain

Anna Brancato,

University of Palermo, Italy

*Correspondence:

Peter Nagele

nagelep@uchicago.edu

tORCID:

Peter Nagele

orcid.org/0000-0001-8369-3858

Specialty section:

This article was submitted to

Psychopharmacology,

a section of the journal

Frontiers in Psychiatry

Received: 20 February 2020 Accepted: 30 June 2020

Published: 17 July 2020

Citation:

Nagele $P$, Brown F, Bass $V$ and Yohanna D (2020) Prolonged

Remission of Major Depressive Disorder After Single Nitrous Oxide

Inhalation Treatment.

Front. Psychiatry 11:692.

doi: 10.3389/fpsyt.2020.00692
Nitrous oxide $\left(\mathrm{N}_{2} \mathrm{O}\right.$, laughing gas) has shown early promise as a rapidly acting treatment for treatmentresistant major depression (1-3). Antidepressant effects of nitrous oxide in these studies started within $2 \mathrm{~h}$ and lasted up to 1 week. Due to the study design, however, it was impossible to determine whether antidepressant efficacy lasted beyond 1 week after nitrous oxide administration. There is currently no evidence showing how long antidepressant effects of nitrous oxide last. Here, we present a case where a patient with severe recurrent treatment resistant major depression experienced full remission, which lasted more than 1 month, after a single nitrous oxide inhalation treatment.

\section{CASE REPORT}

Mr. X is a 41-year-old, married male patient with a more than 15 -year history of unipolar depression. His first episode occurred during graduate school, was unsuccessfully treated with cognitive behavioral therapy alone, and lasted for 1 year. Subsequently, fluoxetine was tried (initially $20 \mathrm{mg} /$ day for 6 months then increased to $60 \mathrm{mg} /$ day for 6 months) but failed, and so the patient was switched to bupropion $(150 \mathrm{mg} / \mathrm{d})$ which resulted in improvement and ultimate remission. The patient did well up to 1 year prior to evaluation for his current depression. The precipitant of his current depression was due to unresolved marital discourse. During that year marital therapy, cognitive behavioral therapy, and adequate antidepressant treatment (bupropion initially $300 \mathrm{mg} / \mathrm{d}$ for 6 months, then $450 \mathrm{mg} / \mathrm{d}$ ) were ineffective to relieve his depression. The patient approached us whether a treatment with nitrous oxide could be considered. In mid-December 2019 in our initial evaluation, the patient was severely depressed (PHQ-9 [Patient Health Questionnaire]: 22; GAD-7 [Generalized Anxiety Disorder Scale): 14) and after excluding potential contraindications for nitrous oxide (such as chronic vitamin $B_{12}$ deficiency, middle ear occlusion) (4) and providing informed consent, we treated the patient with $50 \%$ nitrous oxide (mixed with $50 \%$ oxygen) inhalation (Porter Sentry Sedate MXR-D, Porter Instrument Division, Parker Hannifin, Hatfield, $\mathrm{PA}$ ) for $1 \mathrm{~h}$ under continuous standard monitoring conditions (pulse oximetry, non-invasive blood pressure, ECG, end-tidal $\mathrm{CO}_{2}$ ) with an attending anesthesiologist continuously present. The patient experienced the treatment without any adverse events and recovered within a few minutes after cessation of gas administration. Within half an hour, the patient showed improved symptoms (smiling, whistling); on the next day, the patient reported reduced fear, increased joy, and overall 
improved symptoms. A month later (end of January 2020), the patient reported a PHQ-9 score of 0, indicating full remission, and again in mid-February he reported a PHQ-9 score of 0 . We prescribed mirtazapine $15 \mathrm{mg}$ for depression, poor sleep, and poor appetite, but due to the rapid improvement in symptoms, he decided not to take it.

While only a single case report, it represents evidence that a single 1 -h inhalation treatment with $50 \%$ nitrous oxide may improve and even remit major depressive disorder for more than a month (4). The mechanism of nitrous oxide's antidepressant effect is poorly understood and it presumed to involve NMDAreceptor antagonism (5).

\section{REFERENCES}

1. Nagele P, Duma A, Kopec M, Gebara MA, Parsoei A, Walker M, et al. Nitrous Oxide for Treatment-Resistant Major Depression: A Proof-of-Concept Trial. Biol Psychiatry (2015) 78:10-8. doi: 10.1016/j.biopsych.2014.11.016

2. Zorumski CF, Nagele P, Mennerick S, Conway CR. Treatment-Resistant Major Depression: Rationale for NMDA Receptors as Targets and Nitrous Oxide as Therapy. Front Psychiatry (2015) 6:172. doi: 10.3389/fpsyt.2015.00172

3. Henter ID, de Sousa RT, Zarate CAJr. Glutamatergic Modulators in Depression. Harv Rev Psychiatry (2018) 26:307-19. doi: 10.1097/HRP.0000000000000183

4. Nagele P, Zorumski CF, Conway C. Exploring Nitrous Oxide as Treatment of Mood Disorders: Basic Concepts. J Clin Psychopharmacol (2018) 38:144-8. doi: 10.1097/JCP.0000000000000837

5. Kalmoe MC, Janski AM, Zorumski CF, Nagele P, Palanca BJ, Conway CR. Ketamine and nitrous oxide: The evolution of NMDA receptor antagonists as antidepressant agents. J Neurol Sci (2020) 412:116778. doi: 10.1016/j.jns.2020.116778

\section{ETHICS STATEMENT}

Written informed consent was obtained from the individual(s) for the publication of any potentially identifiable images or data included in this article.

\section{AUTHOR CONTRIBUTIONS}

PN drafted the report. FB, VB, and DY edited the report and made important intellectual contributions to the draft.

Conflict of Interest: $\mathrm{PN}$ is currently receiving funding from NIMH, American Foundation for Prevention of Suicide, Brain Behavior Foundation, and has received research funding and honoraria from Roche Diagnostics and Abbott Diagnostics.

The remaining authors declare that the research was conducted in the absence of any commercial or financial relationships that could be construed as a potential conflict of interest.

Copyright (c) 2020 Nagele, Brown, Bass and Yohanna. This is an open-access article distributed under the terms of the Creative Commons Attribution License (CC BY). The use, distribution or reproduction in other forums is permitted, provided the original author(s) and the copyright owner(s) are credited and that the original publication in this journal is cited, in accordance with accepted academic practice. No use, distribution or reproduction is permitted which does not comply with these terms. 